I University of Oslo Ringgold Standard Institution,

Social Anthropology, Oslo, Norway

trakopoulos@gmail.com

https://orcid.org/0000-0003-1902-0274

Theodoros Rakopoulos'

\title{
SELF IN (AND WITH) THE WORLD: KEITH HART'S MEMOIR
}

Hart, Keith. (2018). Self in the world. Unpublished manuscript, 240 pages.

To 'educate' means 'to lead out,' to lead the self on the voyage of life into the world's affairs. The Germanic intellectual world has mastered the idea of writing about one's education as Bildung, and the modern bourgeois form taken by this kind of confessional writing was the Bildungsroman. A reasoned endeavour, but one thoroughly rooted in a romantic take on the self in the world. Contemplating Mediterranean ruins provided the mind with perspective, establishing a relationship in time and with time, as well as a relationship between the self and the world over time.

The journey of an anthropologist who has followed the movement of Africans across the world, making himself as mobile as them, is an entirely different story. This is the case with Keith Hart's book of his life. Anthropology has been attacked for its colonial past and praised for proposing a real connection of self and other, taking other people's voices seriously when trying to listen to and understand our own. This is such a narrative.

A good memoir can offer an analytical narrative of places in the self's journey, but also the shift in the formation of that very self by the end of that journey. This end is reached through writing: it is the finishing point of a trip and a completion, an aim achieved. I shall accentuate some threads that weave together Keith's intellectual placement of self in the world, drawing on his life story ("in the world," twothirds of the book) rather than his general reflections "on the world." 
Being human in the world neces sarily sits in places. One of them is his Durban flat. It contains the entire works of Mohandas K Gandhi, who lived in the city for two decades. Alongside all of Lenin's works and a poster of Kwame Nkrumah, who fell from power in a coup d'état while the young ethnographer was undertaking fieldwork in Accra's slums. Michael Caine's autobiography is there too, where he celebrates his own journey in the world, his love for movement and America, and his Cockney origins. The connections with Keith's story are strong. Above all, he is a teacher, one of the greatest I have known, and his book cannot help being didactic in part: "This book is an account of my education, an excavation of memory for the purposes of self-knowledge, if you like. But its aim is also to allow readers to reflect on their own education".

The book's theme is the making of world society in our times, as seen through one man's journey. Keith was one of the first anthropologists to note the internet's powerful role in this historical process. His interest in integrating world affairs into anthropology has brought him more recognition outside the discipline than within it. British, American and even French anthropology has embraced narrow localism at the expense of any kind of cosmopolitan endeavour:

The social sciences have focused on the types of social organization and divisions of class, race, gender, religion and nationality that mediate the personal and impersonal dimensions of our existence rather than consider human personality and humanity as a whole.

And so the philosophical humanism that inspires Keith Hart has been replaced by a Boasian cultural relativism.

"Self in the world" is not a swan song, but rather a forward-looking proposal by a peripatetic scholar for autobiography to be assumed as a central method in any truly global anthropology. For that to happen we must abandon rooted conceptions of the self for a life of movement, imagination, collaboration and ambition. The result is cosmopolitan participation in the world. To such a project Hart brings a political focus on economic anthropology's perennial theme: unequal society as the driver of uneven development. Our author started out from a background that lacked privilege, but succeeded in rubbing shoulders with some who embodied it. The escalator he rode to Cambridge University and beyond was provided by Manchester Grammar School. Britain in the I96os, its cultural revolution marked by the Beatles, offered more chances for upward mobility than our present. Not much is left today of the post-war social consensus that gave Keith his start in life. Nor has Cambridge been weaned off its role as a breeding ground for the national elite. A working-class kid from Manchester made examination-passing in classics his profession and used Cambridge as a launch pad for world travel as an anthropologist. But his classical train- 
ing as a teenager never left him and he soon gave up ethnographic fieldwork to read old books and write about them.

As in Hart's life, the book of his life is also laden with literary inventiveness and the ability to tell a good story always with imagined society in the foreground. The whole text is an exercise in "scaling down the world and scaling up the self." The classical writers of social theory are his means for this undertaking. Karl Marx appears 54 times in the version I read (Durkheim only twice, and Weber four times, Fanon I5 times). Marx's imprint on the world goes well beyond scholarship and indeed extends into the realms of real, lived history that Hart participates in throughout the book. His account of this history is no celebration. Indeed, he counts the anti-colonial revolution, and the uneven development that followed, to be more formative of his thinking than anthropology.

Keith's letter to the Trinidadian writer and revolutionary C L R James ("the only fan letter I ever wrote") is a good case study of his attitude to them both. It is an honest, passionate and spontaneous attempt to engage with someone wholeheartedly. James, mentioned more than 60 times, is the real deal here. The reasons for this are many. Neither James nor Marx were academics. They embody the dialectic of this book - narration of personal life events and meditative reflection upon them and stand at the core of Keith's understanding of his life and times.
They both engaged with the world intellectually and politically, while combining restless movement and historical awareness of its tensions.

Transatlantic capitalism has tragically moulded the lives of many people, brown and white, but especially black.

For much of my professional life, I have shadowed the African diaspora through an Atlantic world whose defining moment was slavery. I trace my self-reinvention in mid-life to a spell in Jamaica during the Ig8os.

The years around I990, when the Soviet Union collapsed, China and India emerged as world powers and the internet went public, saw Keith's emergence as a public intellectual. We need to look tragedy in the face and still retain hope. Keith Hart will be remembered as the main source for the "informal economy" in development studies (see his reflections in the midI 980 s on a decade of usage of the term: Hart, I985). It revealed the agency and creativity of Africans underneath the picture of dull uniformity generated by official statistics. A chapter on his fieldwork in Ghana reveals his own checkered experience there along with the life histories of enterprising local people. A later stint in Jamaica provides more insightful snapshots of local life and musings on method (how to read and take part in history). Both of these experiences fed his last attempt at generalization, "the human economy," realised in South Africa as a research program replete with $\mathrm{PhD}$ and post-doc researchers from everywhere (see Hart, 2017). 
Keith is a historian of ideas, an intensely - but never loudly - political person and world citizen, always keenly aware that he stands on the shoulders of giants. He works with anti-colonial revolutionaries as a humanitarian scholar (see Hart, 2009). This cosmopolitan outlook is profound, but it also has deep roots in working-class Manchester. "I come from Manchester" is the title of his opening chapter. When accused in Jamaica of being a beneficiary of English enrichment at their ancestors' expense, he replies, "I am not English, I'm from Manchester." This answer speaks to a refusal of nation-state methodology.

The language of the book is the oral Keith, obvious to anyone who knows him, perhaps not to everyone else. It is ironic that people get to write their autobiographies when they become septuagenarians. Maybe we should write two of them, one in our 40s, when we are closer to our youth, and the other in our 7os. In fact, Keith did write one in his 4os, but was told not to publish it, since it was "too brutal." His accounts of his early years are vivid and moving. He never mentions psychoanalysis or similar approaches. Yet he clearly believes that childhood is formative. $\mathrm{He}$ came from a family of singers and music is a foundation of his personality. He credits listening to Dvo ak's New World Symphony as a boy with the appeal of America later.

Movement in the North Atlantic has inspired and rejuvenated him throughout his life: "The North At- lantic has some claim to being the crucible of modern world history; but it is not the world. Nor is movement in the world the world itself".

That movement has had bumps in the road. The poignant pages describing a brilliant mind's collapse in the midst of a stunning career at Yale are enthralling. At this time, Keith turned to writing poetry, some of which is reproduced here.

There may be too much detail here on academic conflicts. But the glimpses of institutional life in the Ivy League and Midwest have their interest. Here is a Chicago party for his 4oth birthday:

\footnotetext{
Until then I imagined I could be anything - a politician, businessman, journalist. At that party I told myself "Who are you kidding, Keithy? You have now reached the mid-point of your life and have been in school for all of it. If you were ever going to get out, it would have been long before now." This revelation gave me a tremendous surge of freedom. Once I accepted the necessity of being an academic, there were so many different ways that it could be realized. I soon found out what that meant.
}

Returning to Britain, he reflects on where to go and decides on Cambridge: "I was an intellectual more than a United supporter." And an intellectual of varied output, much of it still concealed - and some revealed in this book (like the beautiful late ethnography of Accra). A good memoir reveals the author manque or the secret writer; the back pages of one's life and works. Among many hidden treasures here, I would pick out a 
documentary on Rousseau; the poetry; archaeological reflections; a series of youthful essays that ended up on a pyre.

Keith suffered from mental illness from 35 to 50, when it cleared up. These years were very difficult, and I find it amazing that he can be so open about being bipolar, so genuine about mental health. "I was now convinced that I was suffering from an objective, scientifically identifiable disease. I would take my pills religiously and hope to get over it all eventually."

"Jamaica radicalized me," Keith writes. It turned him towards an explicitly engaged and political anthropology, building on his experience of the developmental industry in the I970s. He co-wrote the development program for Papua New Guinea's independence and a handbook on West African agriculture for USAID. In the I990s, he took on the Nigerian military and brought together the opposed sides in Angola's war. This engagement is the lifeblood of the book and the driving force of his life. It might come as a surprise to many that someone who was long subject to depression and never joined a political party would choose a life of such commitment to making a difference. But there we are.

Some of Keith's choices reveal a deep humanity: for example, ditching the best job offer he ever had to spend time with C L R James and Anna Grimshaw sheds light on the idiosyncratic form of Hart's engagement. His is a real human economy, in the sense of dedicating one's own time in this world to producing, allocating and consuming resources.

The book's title, "Self in the world," is a profoundly current and timely - even urgent - way to think about engaged anthropology. These are the memories of a man in his mid-7os; most readers are likely to be younger and live in a harder world. But Keith's personal engagement of fers us a methodology. Anthropology is about caring and understanding; the two are inseparable. Bildung, surely, but also Verstehen, understanding.

Take the economy, for instance, with its numeric coldness. Keith first came up with an idea that stems from direct observation of life. Then he came up with the idea of money as the unity of politics and economics ("heads or tails," Hart, I986). Next, he came up with the theoretical and practical impossibility of disentangling the personal from the impersonal. Meanwhile, with Anna Grimshaw, he launched Prickly Pear Pamphlets as snappy, comprehensible texts written for an educated lay audience. E.P. Thomson wrote that CLR became more radical as he grew older. Maybe Keith got the idea from him.

Keith's website, The Memory Bank, is where he puts everything he writes. He hates the idea of intellectual property and calls digital capitalism "informational feudalism." As director of the Cambridge African Studies Centre, he "attempted to place it in the historical relationship 
between the West and Africa." This led him to excavate Cambridge's central role in the abolition movement around I80o.

Keith is a real enlightenment thinker with a utopian vision, one of the few ecumenical minds remaining in anthropology. Movement is his key virtue:

So what stopped the graduate students that I met from engaging with the world through Cambridge? World society is being formed in our times. This is when the world became unified for good or ill. We are all connected through a single network for exchanging goods, services and information. Our generation has discovered universal connection and movement. We just need to find the forms of association that can put them to good use.

In other words, we must learn how to care for world society and not just ourselves.

Keith is an "engaged intellectual." He became an intellectual historian rather than remain an ethnographer of Africa. It led him to excavate the history of industrial Lancashire as a way of understanding the class system in which he grew up. He came to understand North Atlantic societies as a 'cubist' network: "West Africa seemed familiar: it was an old society, like Britain, where people knew who they were. America was new alright, but I still had not digested its significance. The Caribbean was all of the other three combined".

In shadowing the African diaspora, Keith has crossed the Atlantic several times, like a pendulum in world history and anthropology's development.
Keith has spent the last two decades in Paris with a new family, while remaining highly mobile. He calls it "at home in the world." The internet, to which he has given great effort, is the machine that bridges difference and distance, the virtual and the real. The inventive self meets the general creativity of the collective machine that is the web.

Keith Hart has lived a life among and with others, in completely anthropocentric fashion. He ponders his influences, methods and aims here, in ways that are decidedly humanist.

Received 9/4/2019

Approved I9/9/20I9 


\section{BIBLIOGRAPHY}

Hart, Keith (ed). (20I7). Money in a human economy. New York, Oxford: Berghahn.

Hart, Keith. (2009). An anthropologist in the world revolution, Anthropology Today, 25/6, p. 24-25.

Hart, Keith. (I986). Heads or tails? Two sides of the coin. Man, 2I/4, p. 637-656.

Hart, Keith. (1985). The informal economy. The Cambridge Journal of Anthropology, Io/2, p. 54-58.

Hart, Keith. The Memory Bank: A New Commonwealth. Available at <http://thememorybank.co.uk/>. Accessed I3, October 2019.

Theodoros Rakopoulos is a professor in the Department of Social Anthropology at University of Oslo. He published, among other books, Towards an Anthropology of Wealth: Imagination, substance, value (co-editor, with Knut Rio) (20I9) and From clans to co-ops: Confiscated mafia land in Sicily (2017). 